\title{
Aloisalthella, a new genus of fossil Polyphysacean green algae (Chlorophyta, Dasycladales), with notes on the genus Clypeina (Michelin, 1845)
}

\author{
Bruno R.C. Granier and Alexandre Lethiers
}

\begin{abstract}
Following a preliminary historical survey of the Cenozoic Clypeina marginoporella Michelin, 1845, which is the type species of the respective genus, and of the Mesozoic Clypeina sulcata (Alth, 1882), the point was made that these two species may not be ascribed to the same genus. Accordingly, the new genus Aloisalthella is introduced with Clypeina sulcata as type-species. In addition, the generic diagnosis of Clypeina is amended (i.e., shortened) in order to exclude all features that are not present in its type, e.g., there are no verticils of sterile laterals inserted between successive verticils of fertile laterals. A rather large collection of algae was used to illustrate some key characteristics of these algal taxa as well as a few features rarely observed in $C$. sulcata.
\end{abstract}

Bruno R.C. Granier. Dépt. STU, Fac. Sci. Tech., UBO, 6 avenue Le Gorgeu, CS 93837, 29238 Brest cedex 3, France. bgranier@univ-brest.fr

Alexandre Lethiers. ISTeP - UMR 7193, UPMC - Campus Jussieu, Tour 56-66, 5e étage, Bureau 510 Case courrier 117, 4 place Jussieu, 75005 Paris, France. alexandre.lethiers@upmc.fr

Keywords: fossil green alga; Clypeina; Acetabularia; new genus; Mesozoic; Cenozoic

Submission: 2 September 2018. Acceptance: 22 May 2019.

\section{INTRODUCTION}

Clypeina sulcata (Alth, 1882) is familiar to any petrographer or micropaleontologist who has ever studied uppermost Jurassic Tethysian series. For palaeophycologists, it remains a peculiar fossil green alga in the sense that most Dasycladalean algae mineralize in the form of extracellular or intercellular aragonitic coatings whereas very few species are intracellularly mineralized with primary calcite (e.g., Granier, 2012), which is just one aspect of this singular species. Besides pointing out this particular mineralization type, its revision required re-examination of the type-species of the

Granier, Bruno R.C. and Lethiers, Alexandre. 2019. Aloisalthella, a new genus of fossil Polyphysacean green algae (Chlorophyta, Dasycladales), with notes on the genus Clypeina (Michelin, 1845). Palaeontologia Electronica 22.2.45A 1-20. https://doi.org/10.26879/ 923

palaeo-electronica.org/content/2019/2333-aloisalthella-and-clypeina

Copyright: July 2019 Palaeontological Association.

This is an open access article distributed under the terms of Attribution-NonCommercial-ShareAlike 4.0 International (CC BY-NC-SA 4.0 ), which permits users to copy and redistribute the material in any medium or format, provided it is not used for commercial purposes and the original author and source are credited, with indications if any changes are made.

creativecommons.org/licenses/by-nc-sa/4.0/ 
genus, i.e., C. marginoporella Michelin, 1845, and its definition.

One of the main difficulties faced when studying such large unicellular fossils is that some forms are only found as isolated remains from loose sediment (mostly Cenozoic species, as Clypeina marginoporella) whereas others are only known as random cuts in petrographic thin sections of limestones (mostly Mesozoic species, as C. sulcata). However, in the case of $C$. sulcata, researchers have collected a variety of material over time: weathered rock surfaces (Figures 1.1, 2), isolated remains (Figures 3-4), petrographic thin sections (Figure 5), and SEM imagery (Figure 4).

The review of the most significant elements contributes 1) to building a 3D model of the species Clypeina sulcata, 2) to definitely excluding it from the genus Clypeina, and 3 ) to selecting it as the type of a new genus introduced hereafter.

\section{MATERIAL AND METHODS}

Some material published earlier (Michelin, 1845; Pia, 1920; Pfender, 1927a; Génot, 1987; Granier, 1994; Granier and Boichard, 2017) as well as some unpublished material are re-examined here. Some material come from the E.P. MunierChalmas and J. Pfender collections currently housed at the Universite Pierre et Marie Curie (Paris, France), or from the P. Génot Collection originally stored at the Universite de Nantes (France), recently relocated at the Muséum National d'Histoire Naturelle (Paris, France). Finally, most material (the J. Emberger Collection, as well as the first author's collection) is currently housed at the Université de Bretagne occidentale (Brest, France).

All color photomicrographs were taken under an Olympus SZX7 stereo microscope (with a 5.6X zoom magnification for the thin sections) whereas
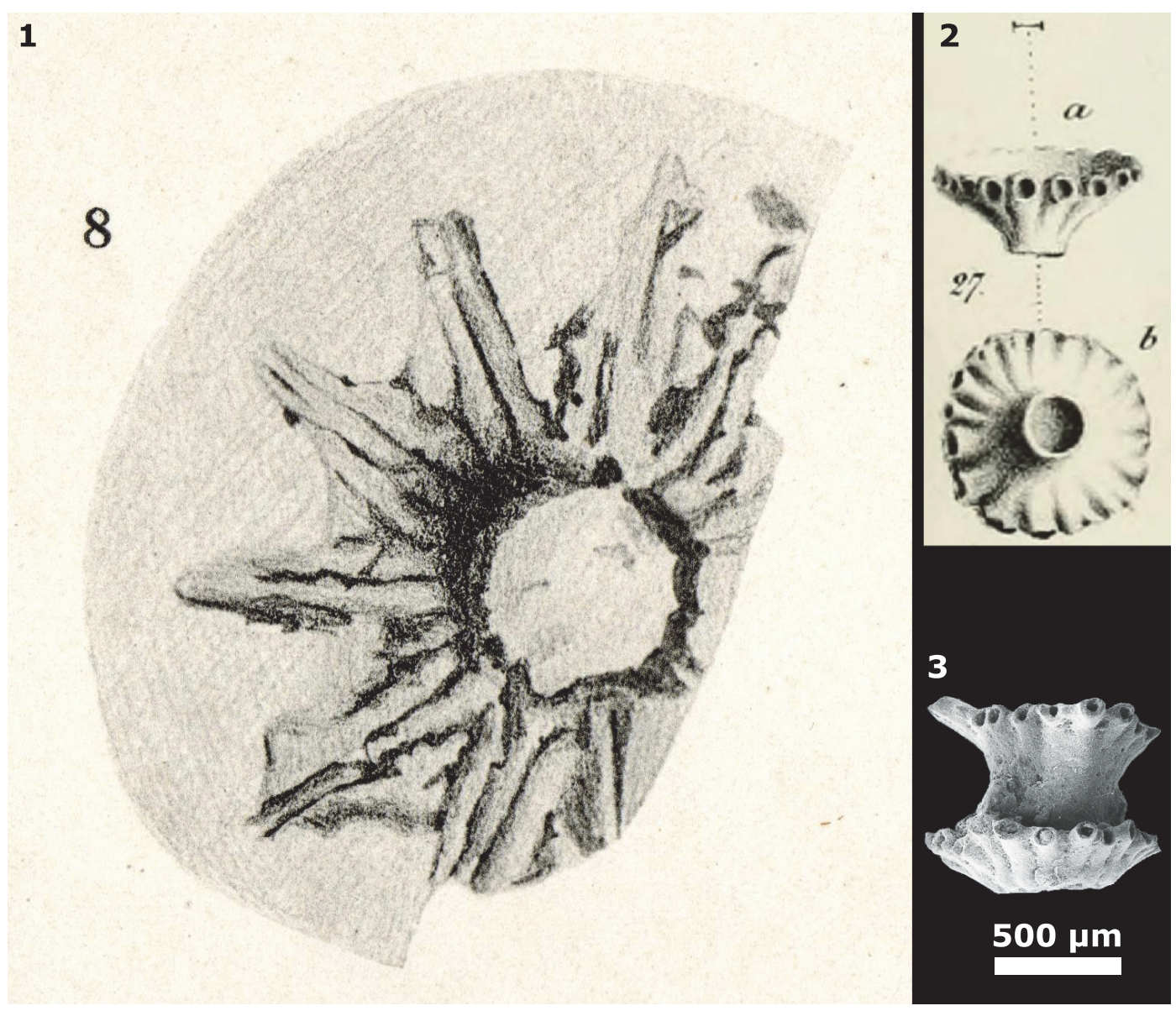

FIGURE 1. 1. Original drawing of "Actinoporella sulcata Alth" (Pia, 1920: plate VII, figure 8). Outer surface of a rock sample from the Tithonian of Nyzhniv, Ukraine. 2. Original drawing of the type of "Clypeina marginiporella" [sic] (Michelin, 1845: plate 46, figure 27.a-b). Étampes, Essone, Paris Basin. 3. Clypeina marginoporella with two whorls joined together. Lutetian of Chambors, Oise, Paris Basin, E.P. Munier-Chalmas Collection (Génot, 1987: plate 26, figure 5). Note the absence of scars between these two fertile whorls (scale bar equals $500 \mu \mathrm{m}$ ). 

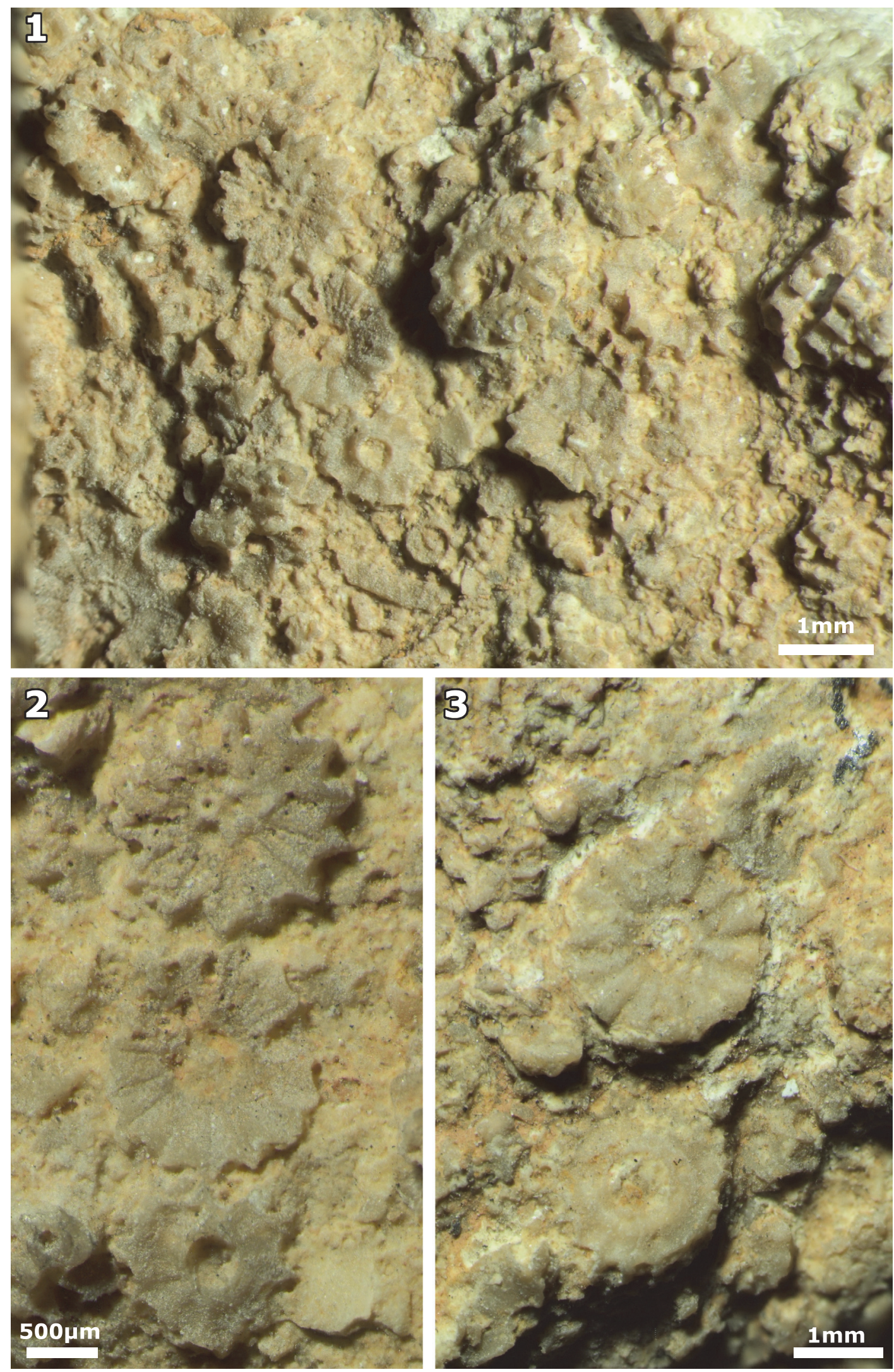

FIGURE 2. Weathered rock surfaces with Aloisalthella gen. nov. sulcata comb. nov., from the Upper Jurassic strata of Algeria, leg. R. Karpoff, J. Emberger Collection (1, 3: scale bar equals $1 \mathrm{~mm}$, 2: scale bar equals $500 \mu \mathrm{m}$ ). 


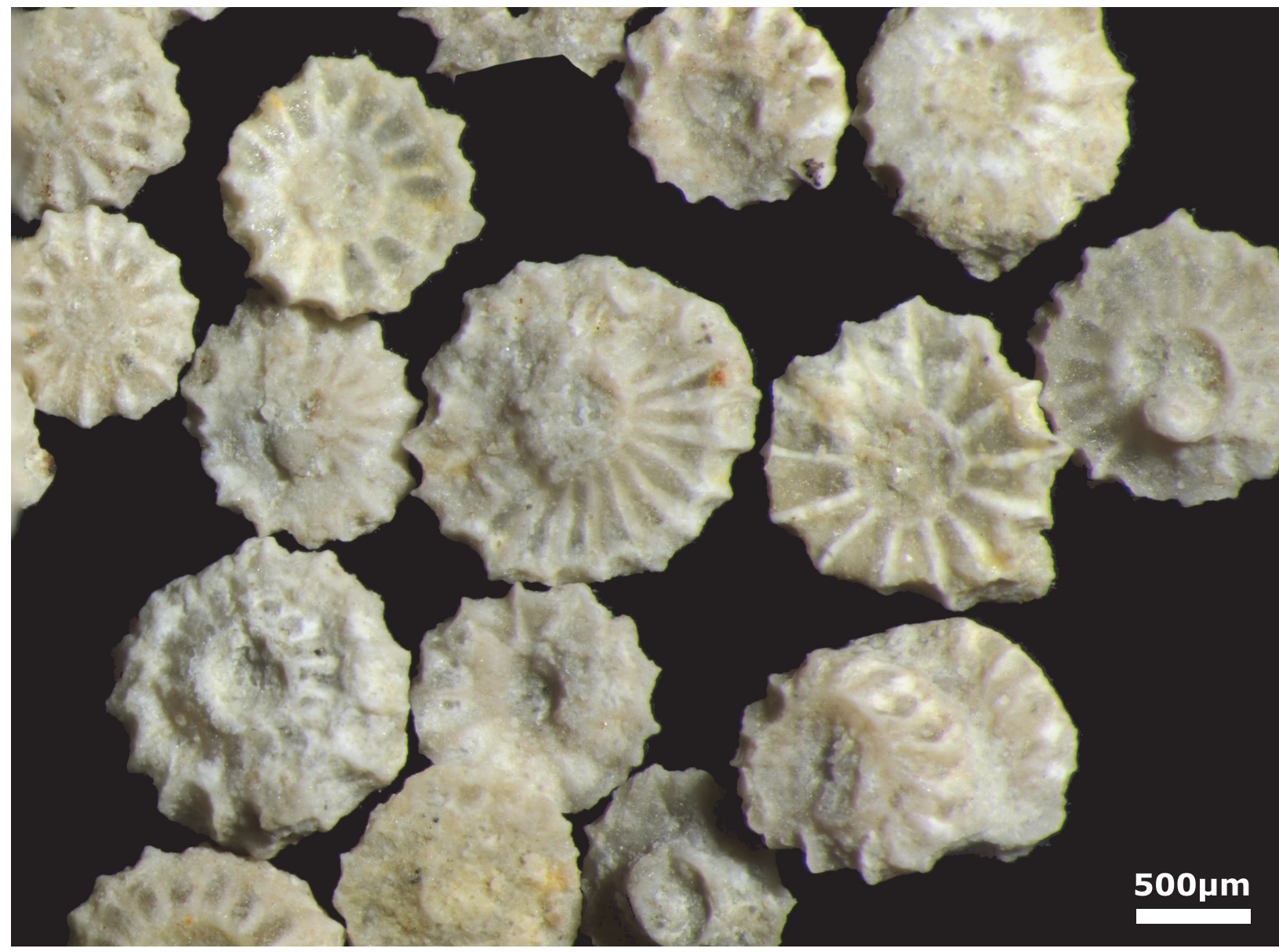

FIGURE 3. Aloisalthella gen. nov. sulcata comb. nov., from the Berriasian of Vuache, Savoie, E France, leg. P.O. Mojon, B. Granier Collection (scale bar equals $500 \mu \mathrm{m}$ ).

black and white photomicrographs, originally gelatin silver photos, were taken using a Zeiss Photomicroscope III and later scanned. SEM pictures were made at Université de Nantes (France) circa 1987: Figures 1.3, 6.1-3, at the TOTAL Scientific and Research Center (Pessac, France) in 1988: Figure 6.4-5, at Université de Bretagne occidentale (Brest, France) in 2010: Figure 4, and at Universidade Estadual Paulista (Rio Claro, SP, Brazil) in 2015: Figure 6.6-10. Finally, the Blender free software (https://www.blender.org/) was used to design $3 \mathrm{D}$ reconstructions of the algae.

\section{HISTORICAL BACKGROUND AND DISCUSSION}

\section{A Digest on the Genus Clypeina, and its Type- Species}

The extinct genus Clypeina (Michelin, 1845) was initially described as belonging to the Class Anthozoa (Michelin, 1845), and then to the Foraminifera (Parker and Jones, 1860), until Munier-
Chalmas (1877) correctly ascribed it to the "Siphonées verticillées", i.e., to the Dasycladales. Today, it includes some 40 species (for Jurassic and Cretaceous species see Bassoullet et al., 1978, and Granier and Deloffre, 1993; for Cenozoic species see Deloffre and Génot, 1982 and Deloffre and Granier, 1992). Its type-species is the middle Eocene-lower Oligocene C. marginoporella (op. cit.: p. 177-178, plate 46, figure 27.a-b; here Figure 1.2).

The fossil consists of a calcareous coating of the algal main axis and its elongated laterals. These laterals, interpreted as gametophores, are regularly arranged in a series of verticils along the main axis. The tubes corresponding to the calcified laterals are open at both ends: in their proximal end because these pores communicate with the axial cavity (in lieu of the main axis) and in their distal end because their calcareous coating is commonly broken there, hence the specific epithet "marginoporella". The generic name is derived from the Latin clipeus, which is a 'round shield', 


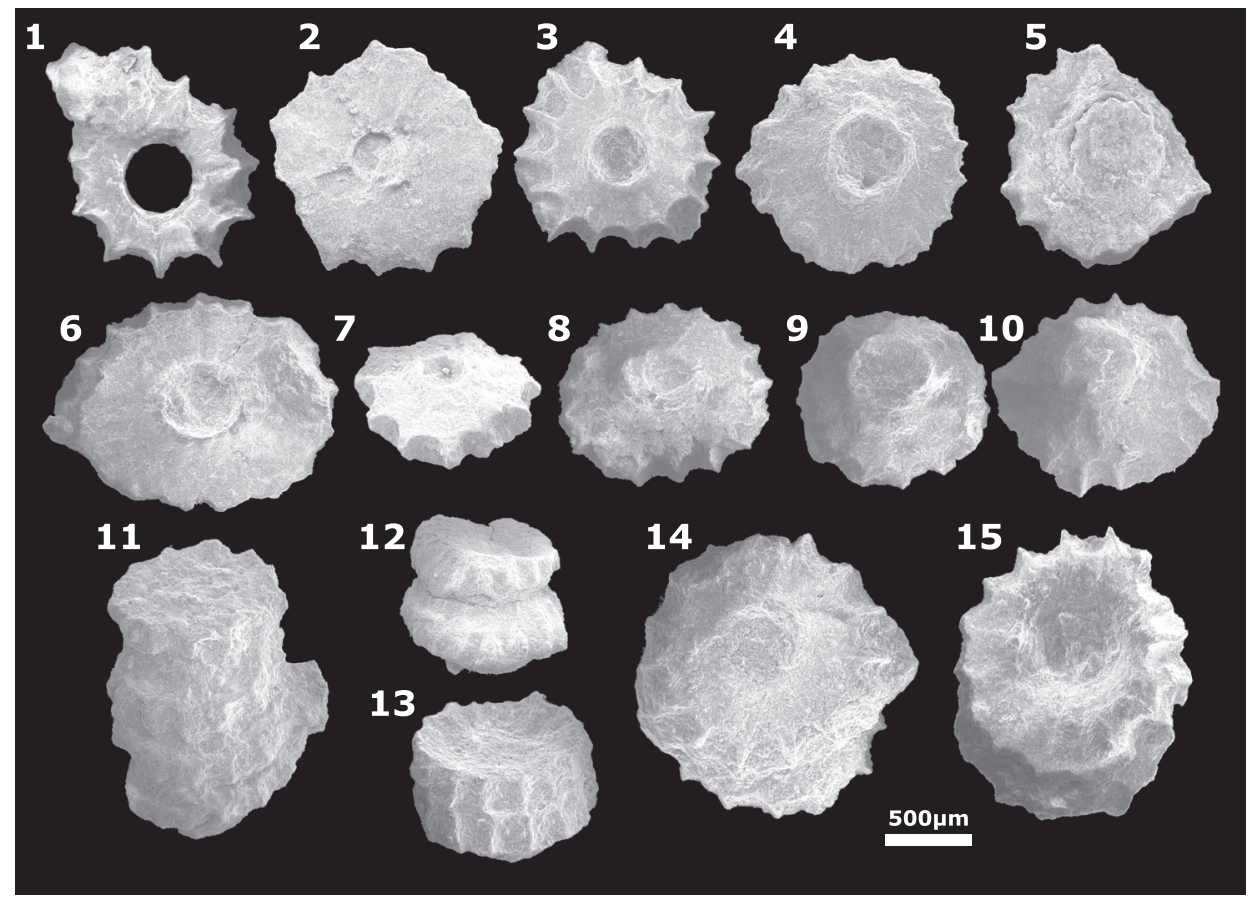

FIGURE 4. Aloisalthella gen. nov. sulcata comb. nov., from the Berriasian of Vuache, Savoie, E France, leg. P.O. Mojon, B. Granier Collection. 1-10. lower side views of single fertile whorls with a neck and upper side views without neck. 11. four (?) successive fertile whorls. 12-15. two (?) successive fertile whorls. All SEM photos same scale (scale bar equals $500 \mu \mathrm{m})$.

and the specific epithet from the Latin margo and porus, respectively 'side' and 'passage'. These close-set tubes are arranged in unfondibuliform rows, i.e., funnel-shaped rows, which are commonly found separated from each other and only rarely attached together.

L. Morellet and J. Morellet (1918) stated that "À côté des ombelles normales, constituées par un verticille de sporanges accolés, s'en trouvent d'autres, d'ailleurs très rares, chez lesquelles la partie évasée de l'entonnoir est fermée par un plancher légèrement bombé, percé de nombreux pores à la façon d'une pomme d'arrosoir. Ce sont les ombelles terminales de la plante" [besides the regular umbels consisting of whorls of joined sporangia, there are other whorls, actually very few, with the flared portion of the funnel sealed by a slightly domed wall, pierced with many holes in the same way as a spray head. They represent the uppermost whorls of the alga]. Few specimens of such algal caps have been documented as "Clypeina sp." by Génot (1987, plate 3, figures 1415; here Figure 6.1-2; unpublished, here Figure 6.3).

\section{Flaws in Earlier Descriptions and Implications}

1) L. Morellet and J. Morellet (1918) stated that "Le plus important de ces fragments se com- pose de huit ombelles (coll. Sorbonne)" [the largest fragment consists of eight umbels (Sorbonne collections)].

This last specimen is not a Clypeina marginoporella because the authors probably referred to the specimen that was later illustrated by Génot (1987: plate 3, figure 13) as C. digitata (Parker and Jones, 1860). Regarding C. marginoporella, Génot (personal communication, 15/10/2016), who investigated the material the Morellet brothers studied and also material of his own, observed a few paired whorls (Génot, 1987: plate 26, figure 5; here Figure 1.3) but never more than two whorls joined together.

2) The Morellet brothers (1918) also stated that "Avec les ombelles, dans les mêmes gisements, existent des fragments de fins tubes calcaires (diamètre moyen $0,3 \mathrm{~mm}$ ), qui correspondent à la partie stérile de la plante (tige). Ils montrent des verticilles espacés de pores par où sortaient les poils végétatifs" [besides the umbels, in the same localities, there are remains made of thin calcareous tubes (with a $0.3 \mathrm{~mm}$ diameter in average), which correspond to the sterile part of the alga (stalk). They show spaced verticils of pores corresponding to exit points of vegetative hairs]. 
1

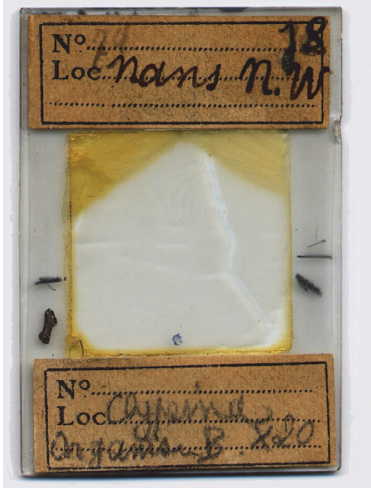

5

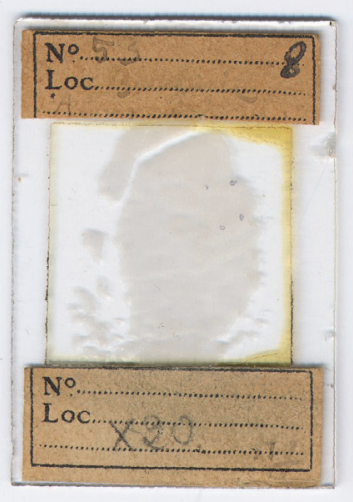

2

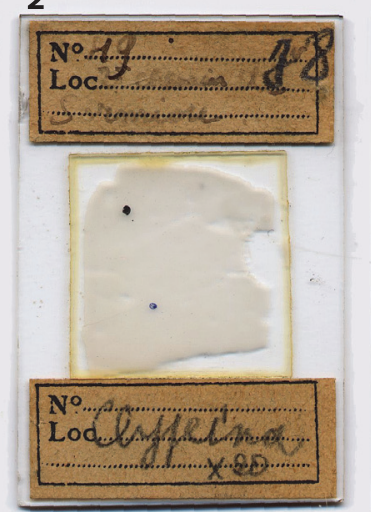

6

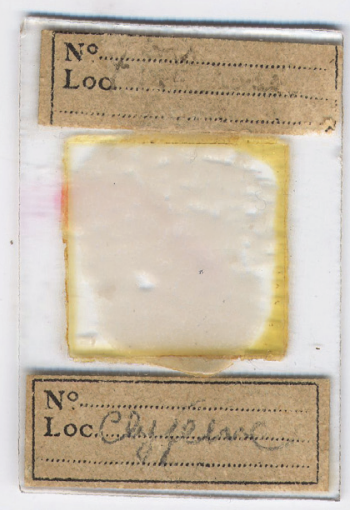

3

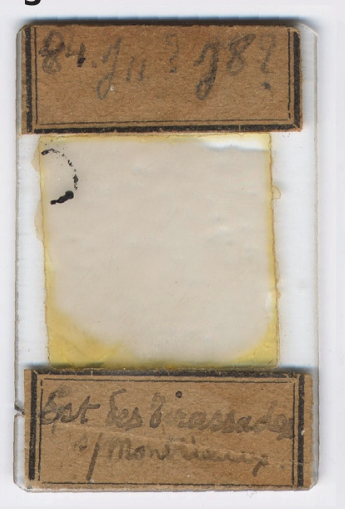

7

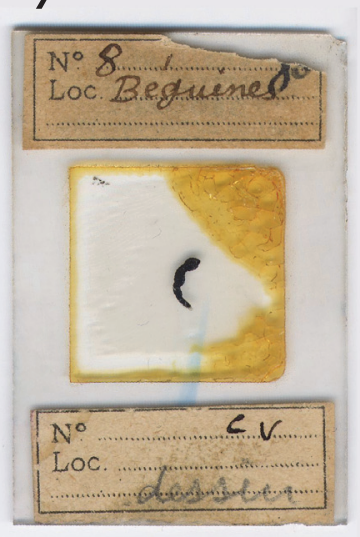

4

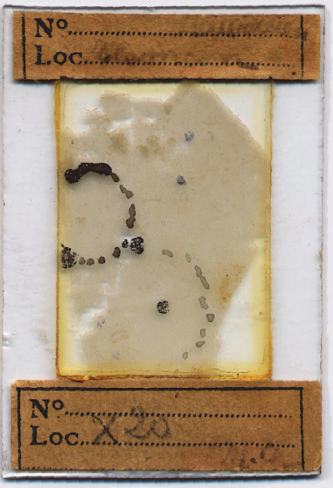

$1 \mathrm{~cm}$

FIGURE 5. Original thin sections studied by Pfender (1927a). 1. no. 79, Nans, Provence, SE France - J. Pfender Collection. 2. no. 18, Sormiou, Provence, SE France - J. Pfender Collection. 3. no. 84, Méounes-lès-Montrieux, Provence, SE France - J. Pfender Collection. 4. without number, Tlemcen, Algeria - leg. Lemesle, E.P. Munier-Chalmas Collection. 5. no. 53, ? label illegible, Provence, SE France - J. Pfender Collection. 6. no. 7 bis, ? label illegible, Provence, SE France - J. Pfender Collection. 7. no. 8, Plan-d'Aups-Sainte-Baume, Provence, SE France - J. Pfender Collection. All photos same scale (scale bar equals $1 \mathrm{~cm}$ ).

It looks like the authors actually described remains known from modern algal genera, e.g., Acetabularia Lamouroux, 1812 (see examples in Granier, 1994: plate 4, figures 5-9; 2012: text-figure 5.A, 5.D; Granier and Boichard, 2017: plate 1, figures 4.a-c, 7; here Figure 6.9-10), but not from Clypeina itself. Elliott (1968) fell into that trap because, when quoting Morellets' work, he said that 'besides typical fertile whorls they have calcified evidence of the sterile portion of the plant" (...). However, Génot (personal communication, 15/10/2016) reported that he never found or observed such features in all the collection material (e.g., Génot, $1978,1980,1987,2009$ ) he examined during his career.

3) In the same publication (L. Morellet and J. Morellet, 1918), the authors propose a graphical 2D reconstruction of Clypeina (op. cit: text-figure 1), that was later re-used by Costantin (1925: text-figure 7.a-b), Pia (1927: text- figure 54), Moret (1943: text-figure 16.10), Rezak (1957: text-figure 1), Endo (1961: plate 5, figure 8), Cita (1964: text-figure 62), Elliott (1968: text-figure 3), L. Emberger (1968: textfigure 93), Bignot (1982: text-figure 6.7; 1985: text-figure 6.7), Berger and Kaever (1992: text-figure 2.20a), and that we used here to build a 3D reconstruction (Figure 7).

To summarize, it looks like the Morellet brothers put forward all the elements, including language elements (e.g., "ombelles"), to definitely link the genus and its representatives to the Family "Acétabulariées" (L. Morellet and J. Morellet, 1918).

As a matter of fact, teratologic cases observed in living Acetabularia crenulata (Lamouroux, 1816) with "several superimposed caps" (e.g., Berger and Kaever, 1992: text-figure 3.61.ac) or Polyphysa parvula (Solms-Laubach) with two superimposed caps (e.g., Valet, 1968: plate 25, fig- 


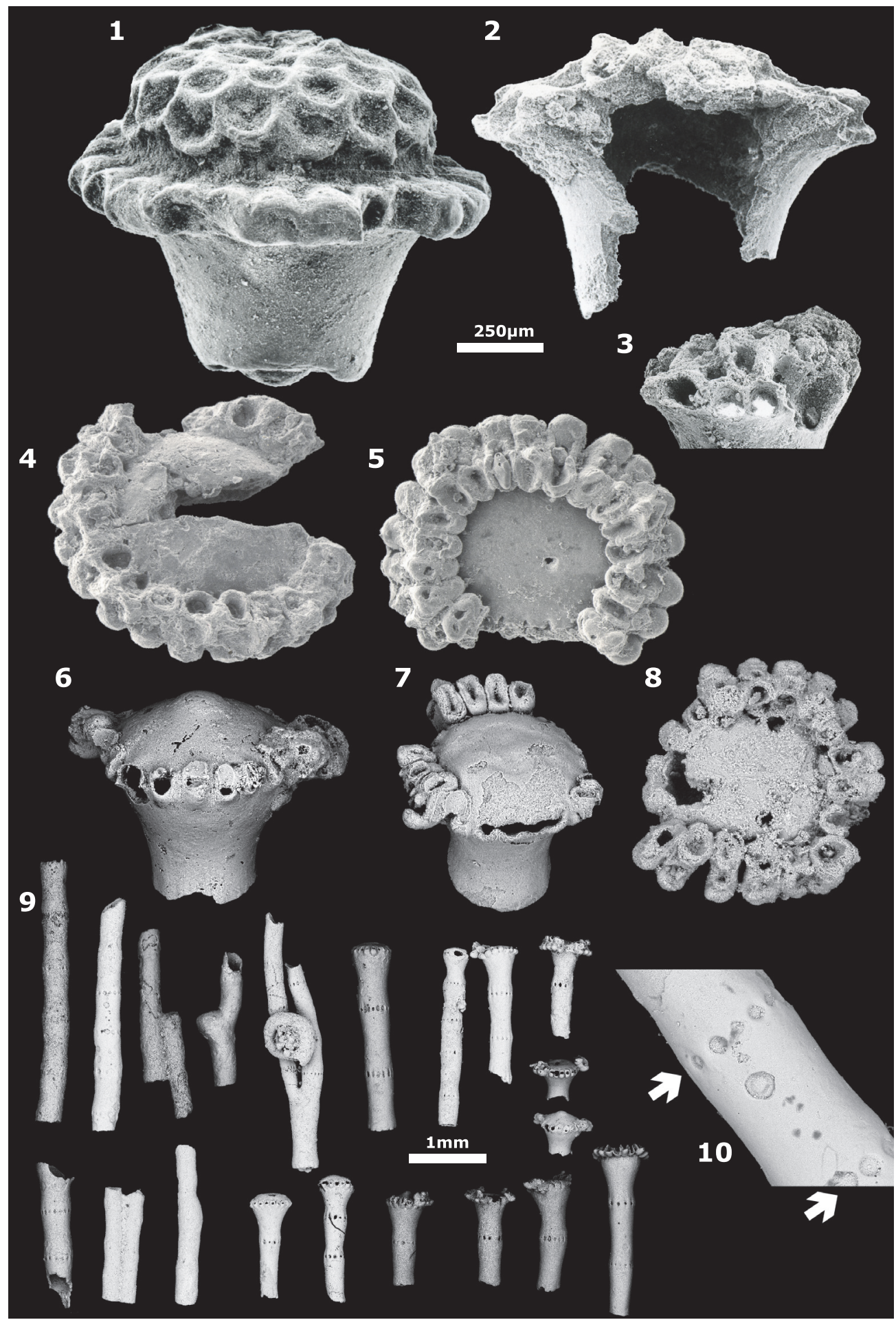

FIGURE 6. 1. Clypeina sp., Lutetian of Montjavoult, Oise, Paris Basin, E.P. Munier-Chalmas Collection (Génot, 1987: plate 3, figure 14). 2. Clypeina sp., Lutetian of Chambors, Oise, Paris Basin, E.P. Munier-Chalmas Collection (Génot, 1987: plate 3, figure 15). 3. Clypeina sp., Lutetian of Thiverval-Grignon, Seine-et-Oise, Paris Basin, P. Génot Collection. 4-10. Acetabularia caliculus Lamouroux in Quoy and Gaimard, 1824, Holocene of Abu Dhabi, UAE, B. Granier Collection: 4-5, 8: top views of the cap; 6-7: side views of the cap; 9: various views of main axes and caps, with or without coronas (note that one rare specimen has a bifurcated thallus); 10: detail of the calcareous coating of a thallus with scars corresponding to the emplacement of former sessile sterile laterals (arrows). Almost all photos same scale (scale bar equals $250 \mu \mathrm{m}$ ), except 9 (scale bar equals $1 \mathrm{~mm}$ ). 


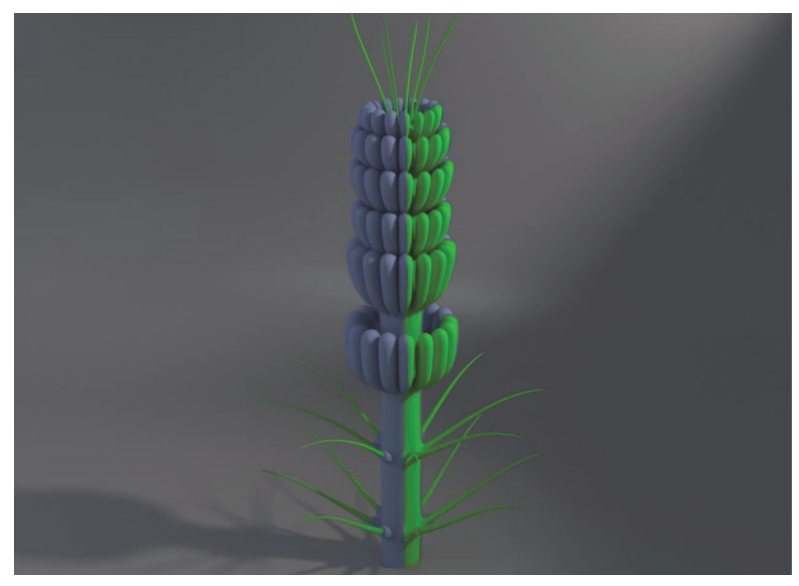

FIGURE 7. 3D reconstruction of the fossil genus Clypeina sensu L. and J. Morellet (1918) based on their 2D reconstruction (op. cit.: text-figure 1). Video of image is available at https://palaeo-electronica.org/content/2019/ 2333-aloisalthella-and-clypeina for download.

ure 4) may suggest that the extinct genus Clypeina is a direct ancestor of the modern genus Acetabularia. However, "the perforate, 'pepper-pot top', structure" (Elliott, 1968) observed in few Clypeina specimens (e.g., Génot, 1987: plate 3, figures 1415; here Figure 6.1-2, plus Figure 6.3) allows this hypothesis to be discarded. As a matter of fact, fossil caps of the living Acetabularia caliculus Lamouroux in Quoy and Gaimard, 1824, e.g., those documented by Granier and Boichard (2017: plate 1, figures 1-3), may have lost either both the corona structure (Figure 6.9 pars) and the gametophores, sometimes called "spicules", or only the gametophores (Granier and Boichard, 2017: plate 1, figures 1-3; here Figure 6.4-8, 6.9 pars), but none of them are perforated (Figure 6.4-8).

Worse than that, flaw number 2 is the most questionable argument ever made by the authors. Although it is plausible that the lowermost portion of the algal thallus was bearing only whorls of sterile hairs, as is the case for instance in most claviform genera, i.e., with club-shaped species (e.g., Petrascula in Pia, 1920, text-figure 23), or as is commonly observed at both ends of the articles in moniliform genera, i.e., with species looking like a string of beads (e.g., Cymopolia in Berger and Kaever, 1992: text-figure 2.10), there is no such evidence in the material studied either by the Morellets or by Génot.

Lastly Bassoullet et al. (1978) gave an emended diagnosis for the genus that supposedly summarizes all earlier findings. According to the second paragraph of their diagnosis, "On peut noter la présence éventuelle de ramifications 'stériles', de forme capillaire, disposées en touffe au sommet de l'algue, en verticilles à sa partie inférieure, et/ou entre les verticilles fertiles" [One can observe the possible presence of hair-like "sterile" laterals, clustered in a tuft at the apex of the algal axis, arranged in verticils in its lower part and/or inserted between the fertile verticils].

By including this last item to cover a feature first observed by Radoičić (1969: text-figure 9.c-d) in "Clypeina jurassica Favre and Richard, 1927" (i.e., Clypeina sulcata), they added another flaw. Actually, this last feature, absence or presence of sterile rows between fertile rows, is a determining criterion applied in the taxonomic classification of the Dasycladales to split genera, tribes or even families (e.g., the Triploporellaceae versus the Polyphysaceae, e.g., Granier, 2015). In no case should it apply to separate species within a single genus.

In conclusion, narrowing the generic diagnosis of Bassoullet et al. (1978: p. 43-44) is suggested, restricting it to its first paragraph and the first part of its last sentence, keeping in mind the possible occurrence of an apical tuft of sterile hairs but excluding any reference to whorls of sterile laterals, which are either not observed or missing in the fossil material. Furthermore, this narrower definition leads to exclusion of $C$. sulcata and some other species from the genus.

\section{A Digest on the Species Clypeina sulcata}

Modern calcareous green algae (Dasycladales and Bryopsidales) mineralize extracellularly or "intercellularly" (in folds of the cell membrane of these large unicellular organisms) with aragonite. Their fossil counterparts are commonly dissolution molds, either empty (in the subsurface), or partly to fully infilled by late calcitic cement. Clypeina sulcata (Alth, 1882) and few allied species mineralize with calcite, commonly yellowish due to organic matter trapped within the crystals (Granier, 2012).

Like the genus Clypeina, the species C. sulcata went through many nomenclatural vicissitudes, such as having to face competitors that will prove to be junior synonyms ( $C$. jurassica Favre and Richard, 1927, and C. inopinata Favre, 1932).

When Alth (1882) introduced the genus Actinoporella based on his species Gyroporella podolica Alth, 1881, from the Upper Jurassic of Galicia (today a Ukrainian western territory), he also described two new species: Actinoporella gümbeli and $A$. sulcata. 
Later, regarding these last two species, Pia (1920) stated that "Während ich (...) die Selbständigkeit Alths Actinoporella gümbeli nicht anzuerkennen vermag, stimme ich mit inm vollständig in der Meinung überein, daß die wenigen Exemplare, die er als Actinoporella sulcata ausgeschieden hat, eine besondere, schon jetzt gut abtrennbare Art vertreten" [Although I may not agree on the singularity of Alth's Actinoporella gümbeli, I fully agree with him to consider that the few specimens he labelled as Actinoporella sulcata belong to a singular discrete species]. Pia (1920, plate VII, figure 8) also provided a drawing of a verticil as seen from the outer surface of a rock sample, i.e., the first ever picture of the alga (Figure 1.1).

In the mean time, Joukowsky and Favre (1913) documented in petrographic thin sections an incertae sedis that they named "Organisme A" from Purbeckian strata of Switzerland. Later, in 1927, these fossil remains were in two instances concurrently ascribed to the genus Clypeina. The first one includes a short note dated February by Pfender (1927b) that announces a forthcoming paper dated September (Pfender, 1927a). The thin sections (Figure 5) she studied are currently stored in the paleontological collections at the Universite Pierre et Marie Curie. Four out of five figures of Pfender (1927a: plate $V$, figures 1-3, 5, not 4; here Figure $8.1,8.5-6,8.10)$, as well as previously unpublished sections from the same material, are documented here in the form of color photomicrographs (Figures 8, 9.6-8, 10.7). The second instance is a short note dated March by Favre (1927) that announces the memoir with the formal definition of $C$. jurassica (Favre and Richard, 1927).

In 1932, Favre again introduces C. inopinata, which is "une espèce voisine" [a closely related species], from lowermost Cretaceous strata of Switzerland. However Remane (1969) who revised the type-material of both Favre's species gave a set of evidences that "make it very doubtful that $C$. inopinata is really an independent species." Bassoullet et al. (1978) conclude that "Clypeina inopinata is probably synonymous of $C$. jurassica." In turn, Granier and Deloffre (1993) synonymize both species with C. sulcata.

There are very few citations of these three taxa in the literature before a paper by J. Morellet (1950), which documents material collected by R. Karpoff in Upper Jurassic strata of Algeria. Color photomicrographs of unpublished material from the same locality and by the same collector, found in the J. Emberger Collection, are illustrated here
(Figure 2). Since J. Morellet's publication (1950), $C$. jurassica has been cited more than a hundred times with peaks in the 1960s and 1970s.

Although Bassoullet et al. (1978) agreed that Actinoporella sulcata "is considered to be a synonym of Clypeina jurassica," they did not implement the priority rule (Art. 11 of the ICBN). Thus, Granier and Deloffre (1993) implemented it in the second part of their reappraisal of the fossil Dasycladalean algae. Since then, the new combination Clypeina sulcata is regularly cited, implying that this name cannot be rejected and that the name $C$. jurassica cannot be conserved.

The reader is referred to Pfender (1927a), J. Morellet (1950), Elliott (1968), Radoičić (1969), and Bassoullet et al. (1978) for more or less detailed diagnoses or descriptions of the species. However, the identification of rows of hair-like laterals, first due to Radoičić (1969), deserves a short dedicated section, as well as few other features never reported before.

\section{Whorls of Sterile Laterals}

As mentioned earlier, Bassoullet et al. (1978) emended the diagnosis of the genus Clypeina in order to encompass $C$. sulcata and its peculiarity: "On peut noter la présence éventuelle de ramifications 'stériles', de forme capillaire, disposées (...) en verticilles (...) entre les verticilles fertiles" [One can observe the possible presence of hair-like "sterile" laterals, arranged (...) in verticils (...) inserted between the fertile verticils]. Granier (1986: text-figure 10) modified Remane's reconstruction (1969: text-figure 23) to take this last remark into account.

In the modern genus Acetabularia, the fine sterile laterals are sessile and do not fossilize, but verticils of scars, left behind after the lateral fall, may be visible (see examples in Granier, 1994: plate 4, figures 5-9; 2012: text-figure 5.A, 5.D; Granier and Boichard, 2017: plate 1, figures 4.a-c, 7; here Figure 6.9-10). Similar features were documented in Clypeina sulcata by Radoičić (1969: text-figures 6.c-d, 9.a-d, 10.a-c) and followers (e.g., Granier, 1986: plate 9, figures d, i; De Castro, 1997: plate 19; plate 20, figures 2-3, 5-6; Schlagintweit et al., 2005: text-figure 35b-d). In our opinion, the recently described $C$. lagustensis Sokač et al., 2014 , with numerous sterile verticils merely represents an ecological variant of $C$. sulcata (Alth, 1882). Sections documenting these sterile laterals are commonly subaxial (Figures 9.3,11) or deep tangential, rarely oblique (Figures 8.4, 9.2b, 10.1) or subtransverse (Figure 12.3, 12.6, 12.9), and the 


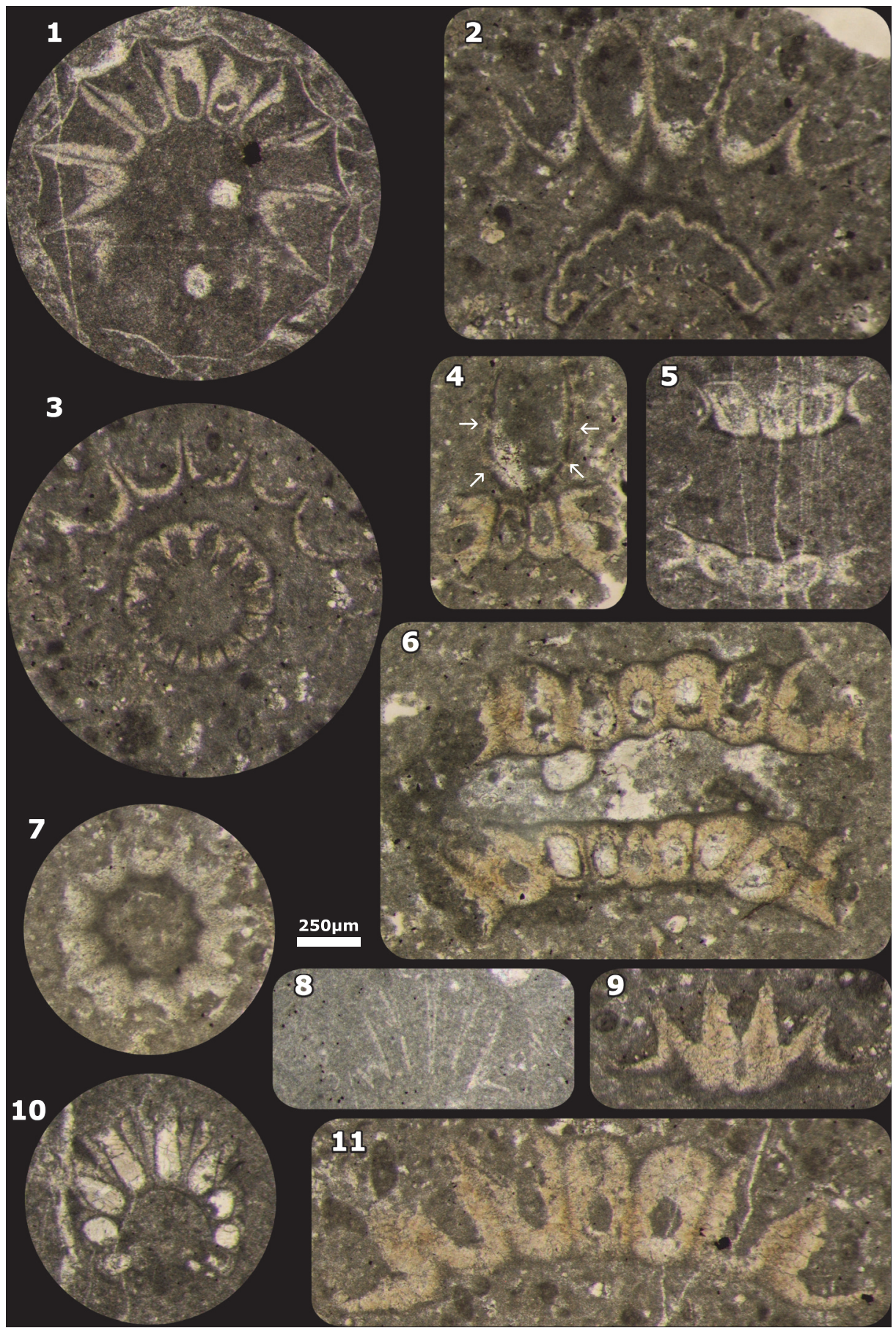

FIGURE 8. 1, 5, 10. Aloisalthella gen. nov. sulcata comb. nov., from the Berriasian of Provence, SE France, J. Pfender Collection. 1: thin section no. 79, Nans, Var: subtransverse section, high in a whorl (= plate V, figure 2 in Pfender, 1927a); 5, 10: thin section no. 49, road from Mazargues to Sormiou, now part of Marseilles' urban area, Bouches-du-Rhône: 5: deep tangential section with two whorls (= plate V, figure 3 in Pfender, 1927a); 10: oblique section in a whorl (= plate V, figure 1 in Pfender, 1927a). 2-4, 6-7, 9, 11. Aloisalthella gen. nov. sulcata comb. nov., from the Kimmeridgian of Tlemcen, NW Algeria, leg. Lemesle, E.P. Munier-Chalmas Collection. 2: oblique section; 3: subtransverse section, low in a whorl; 4: oblique to subaxial section (arrows point to sterile scars along the main axis); 6 : (= plate V, figure 5 in Pfender, 1927a); 7: transverse section, low in a whorl (= text-figure 3.B lower in Pfender, 1927a); 9: tangential oblique section; 11: oblique section of a whorl (= text-figure 3.B upper in Pfender, 1927a). 8. "verticille terminal de poils stériles" according to Pfender (1927a), i.e., uppermost verticil made of sterile hairs (= text-figure 2 in Pfender, 1927a), thin section no. 8, Plan-d'Aups-Sainte-Baume, Var, Berriasian of Provence, SE France, J. Pfender Collection. All photomicrographs same scale (scale bar equals $250 \mu \mathrm{m}$ ). 


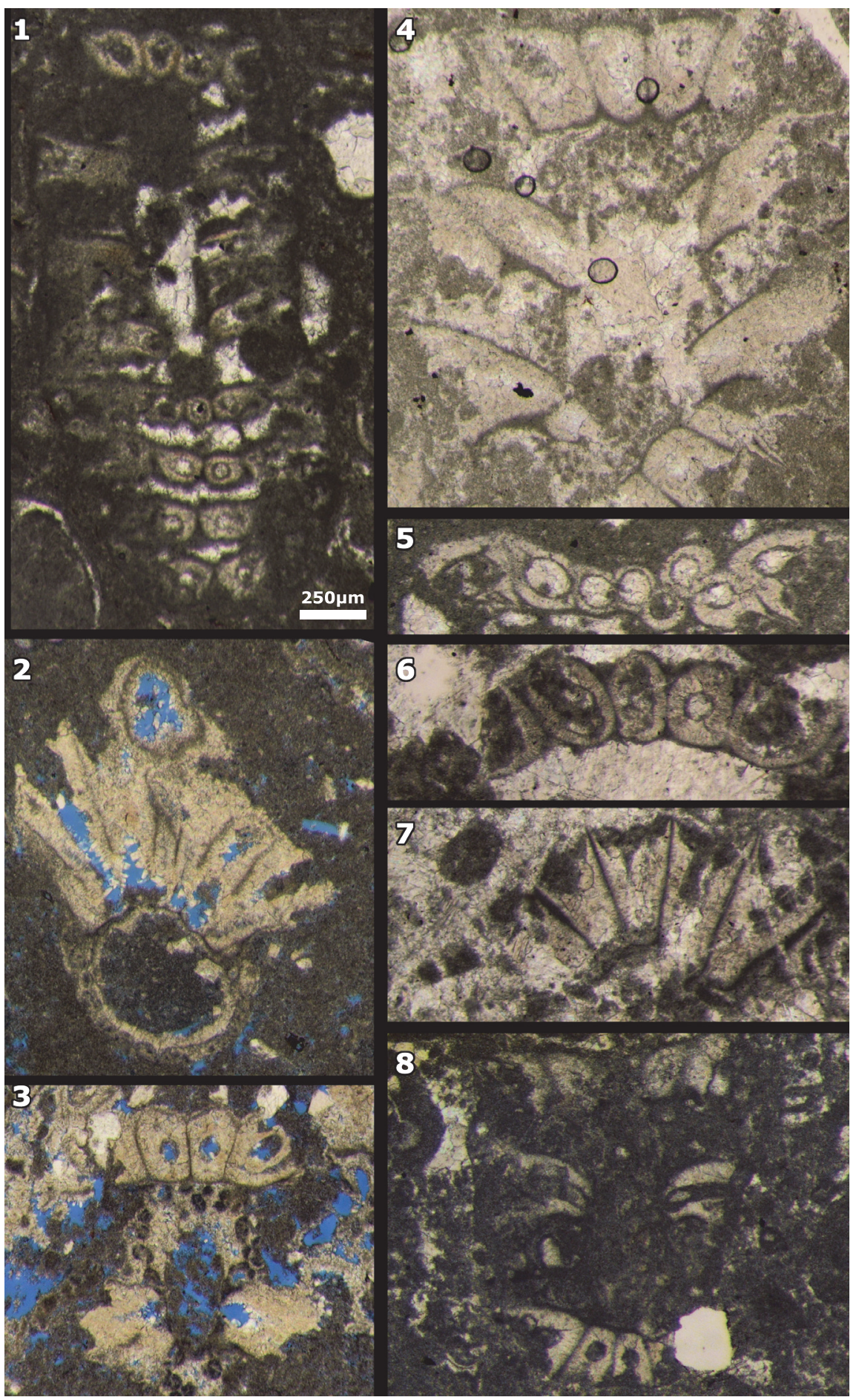

FIGURE 9. Aloisalthella gen. nov. sulcata comb. nov. 1, 4-5. Thin section no. $519 \mathrm{~m}$, Upper Jurassic, PE-1, core 2, Sierra Perenchiza, Valencia, Spain, leg. R. Deloffre, B. Granier Collection. 1: subaxial section with 8 fertile verticils; d: subaxial section with 3 fertile verticils with clots (scars of sterile laterals) in between; e: longitudinal section of an isolated fertile verticil. 2-3. Thin section no. 8878035, Upper Kimmeridgian of Abu Dhabi, United Arab Emirates. 2: subtransverse sections of 2 main axes suggesting a branching of a single thallus; 3 : subaxial section with 2 fertile verticils with clots (scars of sterile laterals) in between. 6-8. Berriasian of Provence, SE France, J. Pfender Collection. 6: longitudinal section of an isolated fertile verticil, thin section no. 7 bis, ? label illegible (= text-figure 3.A lower in Pfender, 1927a); 7: subtransverse section of an isolated fertile verticil, thin section no. 53, ? label illegible (= text-figure 3 .A middle left in Pfender, 1927a); 8: subaxial section with 3 fertile verticils, thin section no. 84, Méounes-lès-Montrieux, Var (= text-figure 1 in Pfender, 1927a). All photomicrographs same scale (scale bar equals $250 \mu \mathrm{m}$ ). 


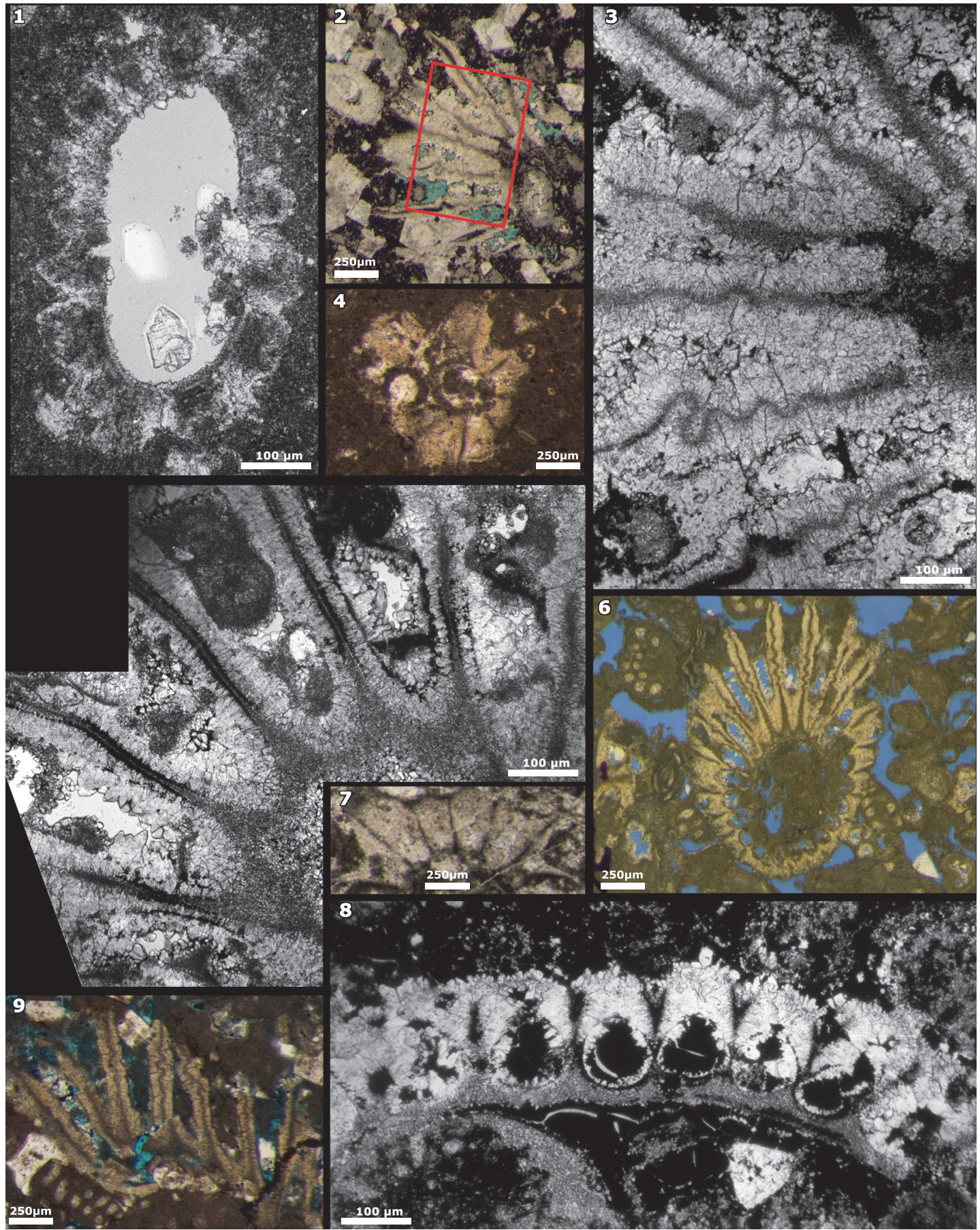

FIGURE 10. Aloisalthella gen. nov. sulcata comb. nov. 1-3, 5-6, 8-9. Upper Kimmeridgian of Abu Dhabi, UAE. 1: subtransverse section of a main axis with pores that correspond to the sterile laterals, thin section no. 8706034; 2-3: subtransverse section of a fertile verticil and detail of its fertile laterals with twisted walls, thin section no. 9855076; 5 : subtransverse section of a fertile verticil with bitumen linings on the walls of its laterals, thin section no. 8822034; 6 : subtransverse section of a fertile verticil with its fertile laterals with twisted walls, thin section no. 8957035; 8: oblique section of a fertile verticil with bitumen linings on the walls of its laterals, thin section no. 8902034; 9: subtransverse section of a fertile verticil with its fertile laterals with twisted walls, thin section no. 9998177. 4. Subtransverse sections of 2 main axes suggesting a branching of a single thallus, thin section no. $519 \mathrm{~m}$, Upper Jurassic, PE-1, core 2, Sierra Perenchiza, Valencia, Spain, leg. R. Deloffre, B. Granier Collection. 7. random section of a fertile verticil, thin section no. 53, ? label illegible (= text-figure 3.A upper left in Pfender, 1927a), Berriasian of Provence, SE France, J. Pfender Collection. 1, 3, 5, 8 (scale bar equals $100 \mu \mathrm{m}$ ), and 2, 4, 6-7, 9 (scale bar equals $250 \mu \mathrm{m}$ ). 
corresponding pores are rarely visible (except for 2 sections illustrated here: Figures 8.4, 10.1).

\section{SYSTEMATIC PALAEONTOLOGY}

(B. Granier)

Phylum CHLOROPHYTA Pascher, 1914

Class DASYCLADOPHYCEAE Hoek et al., 1995

Order DASYCLADALES Pascher, 1931

Family POLYPHYSACEAE (Kützing, 1841)

Genus CLYPEINA Michelin, 1845, emend.

Type species. Clypeina marginoporella Michelin, 1845 , p. 177-178, plate 46, figure 27.a-b; here Figure 1.2.

Emended diagnosis. By discarding features that are not observed on Clypeina marginoporella Michelin, 1845 (the type-species of the genus), we provide a modified, shortened version of the "diagnose émendée" of Bassoullet et al. (1978). These fossil algae have a thallus usually cylindrical bearing laterals of first order only. The main characteristic of the genus is the occurrence of relatively broad laterals, hence supposedly fertile, markedly longer than thicker. They are varyingly inclined with respect to the main axis communicating with it through a pore at their proximal end; they are either open or closed at their distal end. The calcareous coatings of adjacent laterals are usually welded together in their proximal part. They form single whorls more or less regularly spaced along the main axis, but non-contiguous. In exceptional circumstances, one can find scars marking the former emplacements of sessile hair-like laterals, hence supposedly sterile, clustered in a tuft at the apex of the alga. French version with precise identification of the excerpts from the original text: "Algues fossiles" ayant un thalle "de forme généralement cylindrique, ne possédant que des ramifications de premier ordre. Le genre est surtout caractérisé par la présence de ramifications" relativement développées, nettement plus longues que larges, et donc supposées "fertiles". Elles ont une "inclinaison variable par rapport à l'axe principal avec lequel elles communiquent par un pore" dans leur partie proximale; elles sont "ouvertes ou fermées à leur extrémité distale". Les "enveloppes calcaires" de ramifications adjacentes "sont généralement soudées entre elles à leur partie proximale. Elles constituent des verticilles simples plus ou moins régulièrement espacés le long de l'axe, mais non jointifs." Exceptionnellement, on peut observer des cicatrices marquant l'emplacement "de ramifications stériles, de forme capillaire," sessiles, "disposées en touffe au sommet de l'algue”.

Genus ALOISALTHELLA gen. nov.

Type species. Actinoporella sulcata Alth, 1882, p. 323 (Neotype: plate VII, figure 8 in Pia, 1920; here Figure 1.1).

Diagnosis. Fossil algae with a subcylindrical main axis (because its diameter may slightly vary within a single specimen) commonly bearing two types of whorls: 1) more or less widely spaced radiating rays of fertile laterals and, when visible, 2) whorls of tiny pores on the locations of sessile sterile laterals. There are usually several whorls of sterile laterals separating two successive rays of fertile laterals. Fertile whorls consisting of first order laterals welded together at least in their proximal part form a round shield. These fossilized laterals are relatively broad, markedly longer than thicker, and either open (broken) or closed at their distal end.

Etymology. The new genus is dedicated to Alois (Alojzy) Alth (1819-1886), the author of the species Actinoporella podolica, i.e., the type-species of the genus Actinoporella (Gümbel in Alth, 1882) (see Granier, 2019a), and of the type-species of the new genus.

Aloisalthella sulcata Alth, 1882, comb. nov. Figures 1.1, 2-4, 8.1-7, 8.9-11, 9-12

1882 A. sulcata Alth. Alth, p. 323.

1913 "Organisme A". Joukowsky and Favre, p. 315, text-figure 6, pl. XIV, figure 2.

1920 Actinoporella sulcata Alth. Pia, p. 100-101, plate VII, figure 8.

1927b "Organisme A" / Clypeina. Pfender, p. 28.

1927 Clypeina jurassica. Favre, p. 49-50.

1927 Clypeina jurassica n. sp. Favre and Richard, p. 34-35, text-figure 10.a-u; plate I, figures 2-3.

1927a "Organisme A" / Clypeina jurassica. Pfender, p. 89-94, France: text-figures 1, 3.A; non text-figure 2; plate $\mathrm{V}$, figures 1-3; Algeria: text-figure 3.B; plate $\mathrm{V}$, figures 4-5; Switzerland: text-figure 4 (= text-figure 6 in Joukowsky and Favre, 1913).

1932 Clypeina inopinata n. sp. Favre, p. 11-16, textfigure 1.1-28.

1932 Clypeina jurassica J. Favre. Favre, text-figure 2.1-17.

1943 Clypeina jurassica. Moret, text-figure 16.13 pars (= text-figure 10.b, 10.e, 10.n in Favre and Richard, 1927).

1950 Clypeina jurassica J. Favre. J. Morellet, plate XXII, figures 1-3.

1955 Clypeina jurassica J. Favre. J. Emberger, p. 545, text-figure 1.1-16. 

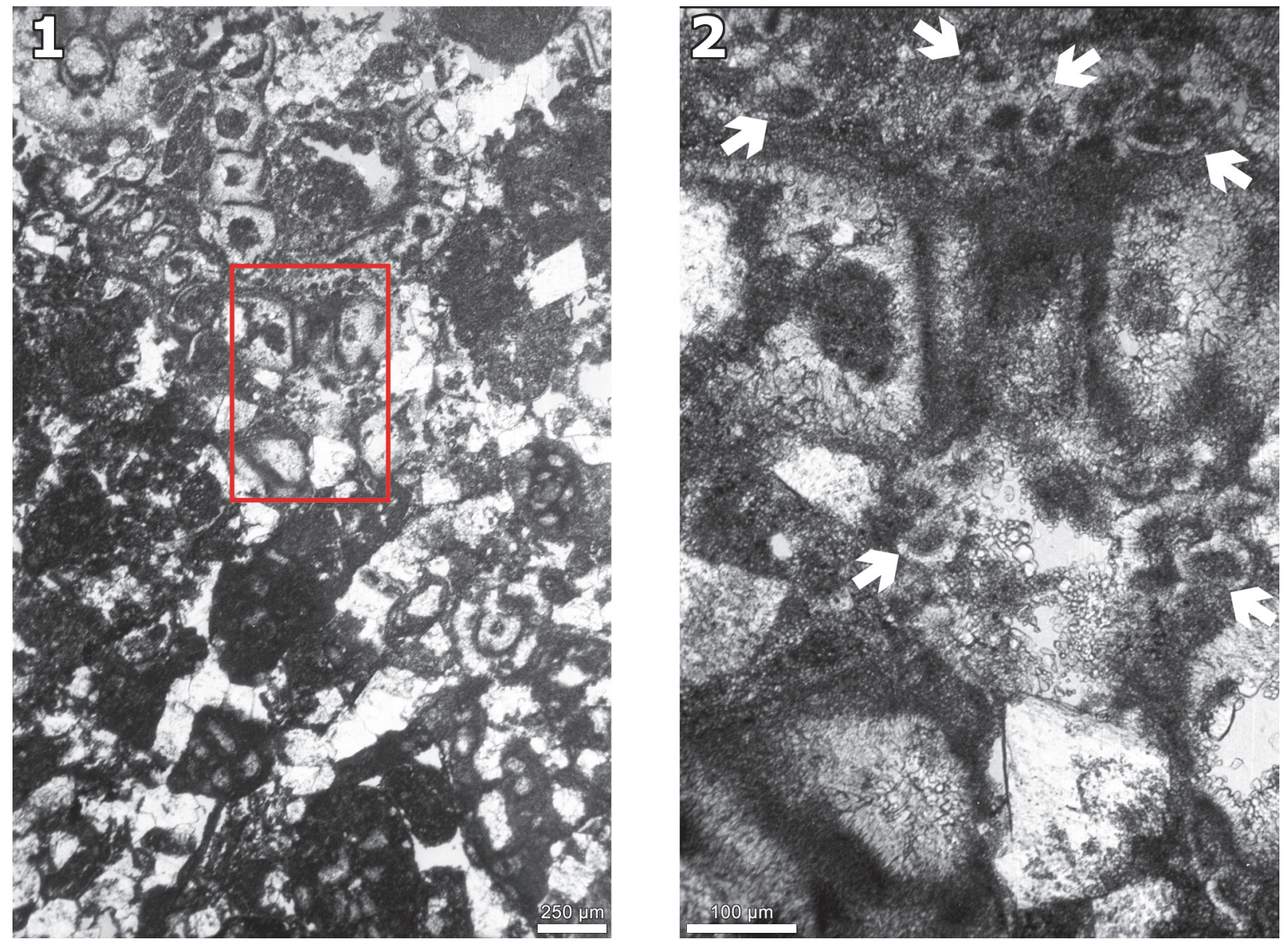

FIGURE 11. Aloisalthella gen. nov. sulcata comb. nov. Thin section no. 8730034, Upper Kimmeridgian of Abu Dhabi, UAE. 1. microfacies (scale bar equals $250 \mu \mathrm{m}$ ). 2. arrows pointing to some scars (clots) of sterile laterals (scale bar equals $100 \mu \mathrm{m})$.

1960 Clypeina jurassica J. Favre. J. Emberger, textfigures 5.a, 10.a, 12.2.

1964 Actinoporella sulcata Alth. Johnson, p. 12-13, plate 10 , figure 7 (= plate VII, figure 8 in Pia, 1920).

1968 Clypeina jurassica Favre. Elliott, p. 29-32, plate 3, figures 2-5; plate 4, figures 4-6.

1968 Clypeina inopinata Favre. Elliott, p. 32.

1969 Clypeina jurassica Favre in Favre and Richard, 1927. Remane, p. 106-108, text-figures 1.a-i, 2.a-d, 3.a-g, 4.a-e, 5.a-e, 6, 7.a-g, 8, 9.a-f, 10.ah, 11.a-c, 12.a-d, 13.a-c, 14.a-f, 15.a-c, 16.a-d, 17.a-c, 18.a-f, 19, 20.a-b, 21, 22.a-f, 24.a-d, 25.a-e, 26.a.-g, 27.a-h, 28.a-d, 29.a-h, 30.a-d, 31-45.

1969 Clypeina jurassica Favre. Radoičić, p. 81, textfigures 6.a-b, 9.c-d.

1969 Clypeina inopinata Favre. Radoičić, p. 75-81, text-figures 6.c-d, 7.a-d, 8.a-h, 9.a-b, 10.a-c.

1974 Actinoporella sulcata Alth. Conrad et al., p. 5, text-figure 2.8 (= plate VII, figure 8 in $\mathrm{Pia}$, 1920).
1978 Clypeina jurassica Favre and Richard, 1927 Bassoullet et al., p. 49-52, plate 4, figures 4 (= text-figure 9.c in Radoičić, 1969), 5, 7 (= textfigure 10.a-n in Favre and Richard, 1927).

1978 Clypeina inopinata Favre. Bassoullet et al., p. 48-49.

1982 Clypeina. Bignot, fig. 6.8.A (= text-figure 24.b in Remane, 1969), 6.8.B (= text-figure 29.c pars in Remane, 1969).

1985 "dasycladacean chlorophytes". Bignot, text-figure 6.8.A-B (= text-figure 6.8.A-B in Bignot, 1982).

1986 Clypeina jurassica Favre in Favre and Richard, 1927. Granier, p. 44-46, plate 9, figures a-d, i-k.

1993 Clypeina sulcata (Alth). Granier and Deloffre, p. 27.

1994 Clypeina sulcata (Alth). Granier, p. 81, plate 1, figures 2-3, 5-7.

1997 Clypeina jurassica jurassica Favre in Favre and Richard, 1927. De Castro, p. 196-197, 230-235, plate 2, figures 1-5; plate 19; plate 20 , figures 1 9; plate 21 . 


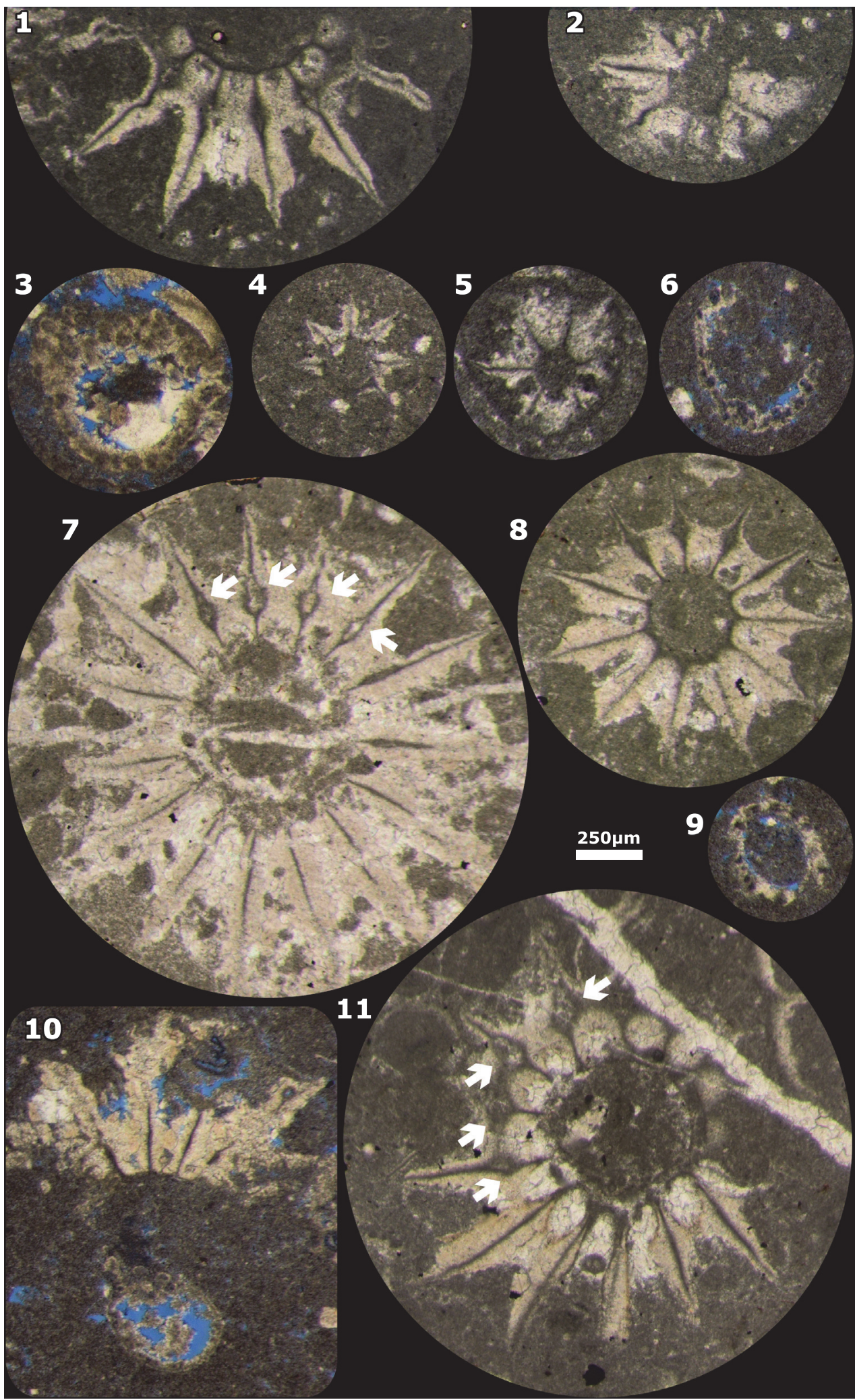

FIGURE 12. Aloisalthella gen. nov. sulcata comb. nov. 1-2, 4-5, 7-8, 11. Upper Jurassic, PE-1, core 2, Sierra Perenchiza, Valencia, Spain, leg. R. Deloffre, B. Granier Collection. 1, 11: thin section no. 519; 2, 8: thin section no. 519.25; 4: thin section no. 519.75; 5: thin section no. 518.50; 7: thin section, 518.75. 3, 6, 9-10. 8878035, Upper Kimmeridgian of Abu Dhabi, UAE, B. Granier Collection. Arrows in 7 and 11 points to places where the laterals are bent (the "elbow"). All photomicrographs same scale (scale bar equals $250 \mu \mathrm{m}$ ). 
2005 Clypeina sulcata (Alth). Schlagintweit et al., p. 51-52, text-figure 35.a-d.

2009 Clypeina jurassica Favre and Richard, 1927. Schlagintweit et al., p. 50-51, text-figure 8.a-b.

2011 Clypeina sulcata (Alth). Mathieu et al., Photos 48.a-b.

2012 Clypeina sulcata (Alth). Granier, p. 46, text-figure 7.D.

2014 Clypeina lagustensis n. sp. Sokač et al., p. 7880, plate I, figures 1-6; plate II, figures 1-6; plate III, figures 3, 6; plate IV, figures 1-8; plate V, figures 1-10; plate VI, figures 1-12.

2014 Clypeina jurassica Favre. Sokač et al., p. 7980, plate III, figures 1-2, 4-5, 7-9.

2019b Clypeina sulcata (Alth). Granier, p. 251, text-figure 12.K, $12 . \mathrm{S}$

2019 Clypeina sulcata (Alth). Granier and Lethiers, p. 38, text-figure.

Remarks. The few remaining sections, rare and atypical specimens, presented below correspond mostly to subsurface material from the Arab oil reservoir of the Abu Dhabi offshore:

Figure 10.5 is an oblique section, high in a fertile verticil. A black bitumen lining occurs in place of the former cell wall. The outer mineralization is micritic (microcrystalline calcite), possibly after a primary aragonite, whereas the inner mineralization is sparitic and consists of primary yellowish fibrous calcite. This inner calcification is limited and properly outlined in the proximal part of the fertile laterals where it molds possible reproductive structures. It then thickens in the median part of the laterals and thins again in their distal part (see also Schlagintweit et al., 2009: text-figure 8). Figure 10.8 is an oblique section, low in a fertile verticil. Here, bitumen linings split, and large ovoid casts with a sharp outline are now visible on the inner part of the fertile laterals.

Figure 10.2-3, 10.6, 10.9 documents uncommon oblique to subtransverse sections of fertile verticils. The walls of adjacent fertile laterals are twisted, a rare phenomenon that occurred before full mineralization take place, probably because the fertile ampulla was still expanding whereas the mineralization had just started. Consequently the unfolding of the inflating fertile ampulla was fossilized at an early stage.

Thalli of $C$. sulcata are commonly abundant but scattered in the sediment, suggesting that the alga formed dense communities, but not as dense as those of Neoteutloporella socialis (Praturlon). Accordingly, the calcareous coatings of neighboring thalli should never join or merge. Figure 9.2 is an odd oblique section. It looks like two thalli have locally joined. A more realistic hypothesis would be

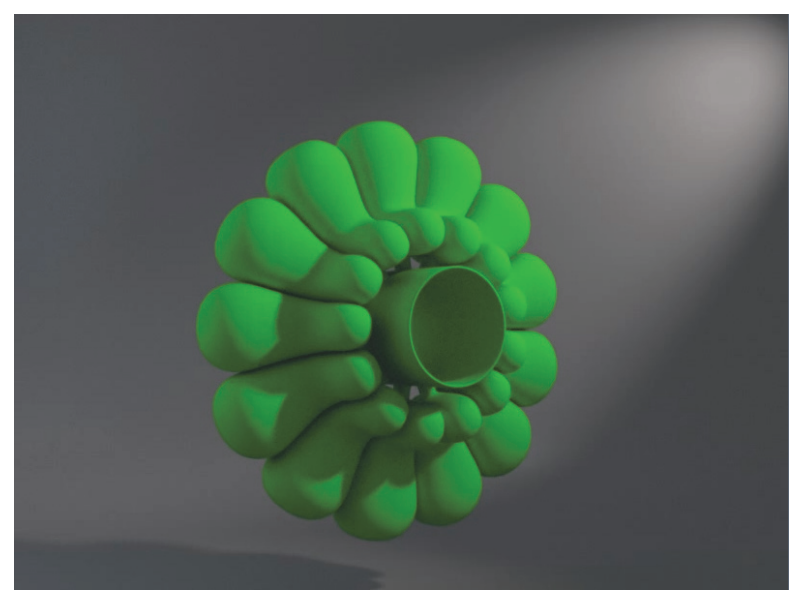

FIGURE 13. 3D reconstruction of an uncalcified fertile verticil of Aloisalthella gen. nov. sulcata comb. nov. It is assumed that on these fertile laterals bulges are located below the row (inferior). Video of image is available at https://palaeo-electronica.org/content/2019/2333-aloisalthella-and-clypeina for download.

that we are dealing with a single thallus that is branching, and the section cuts the two branches just above the branching. Similarly Figure 10.4 from the Upper Jurassic of Spain represents another odd transverse section. Again, the section would cut the branches above a branching, but this time not so close to the branching. Similar dichotomous branching also rarely occurs in the modern Acetabularia (e.g., Valet, 1968: plate 15, figures 56 ; plate 24, figure 3; plate 25, figures 3 , 7; Bonotto et al., 1977: text-figure 6; here Figure 6.9 pars).

As for previous 3D reconstructions of algae (Granier, 2010; Granier and Sander, 2013; Granier and Lethiers, 2017), the Blender free software was used to build 3D models of $C$. sulcata. The models presented here focus 1 ) on the morphology of the fertile laterals (Figure 13) and 2) on the arrangement of the verticils, both sterile (represented by scars) and fertile, along the main axis (Figure 14). Such models enable visualization of truncations of the algal structure (Figure 13) at various angles (Granier and Lethiers, 2019: text-figure; here Figure 15) that can be compared to actual sections (e.g., Figures 8.3, 12.11). In turn these comparisons improve and validate the model.

\section{CONCLUSIONS}

Thalli of representatives of the genus Clypeina, obviously those of the Cenozoic Clypeina marginoporella, may bear sterile hairs at their distal end, but to date only three specimens are known (Figure 6.1-3). It cannot be excluded that they also bear sterile verticils at their proximal end, close to 


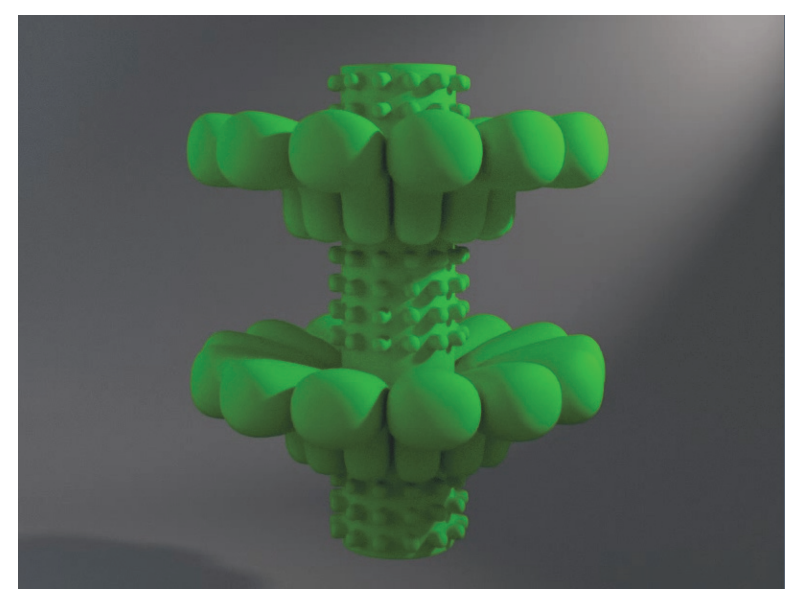

FIGURE 14. 3D reconstruction of an uncalcified living thallus of Aloisalthella gen. nov. sulcata comb. nov., with sets of sterile rows (of scars) in alternation with fertile rows. Video of image is available at https://palaeo-electronica.org/content/2019/2333-aloisalthella-and-clypeina for download.

the rhizoid, but that was never observed. In any case, they do not bear any sterile verticils in alternation with fertile verticils. Fertile verticils are commonly imbricated.

In contrast, thalli of representatives of the newly established genus Aloisalthella, obviously those of the Mesozoic Clypeina sulcata, are commonly bearing more or less widely spaced fertile verticils (not imbricated) with sets of sterile verticils in the intervals, when visible. Unique features of the type-species (possible branching of some thalli and twisted walls of some fertile ampullae) are documented here for the first time.

The corrections made to the generic definition of Clypeina imply launching revisions of all the 40 or so species previously referred to this genus.

\section{ACKNOWLEDGEMENTS}

This publication follows the "Revision of the Juliette Pfender Collection - Part 1" (Granier and D. Dias-Brito, 2016). It was recently presented on the

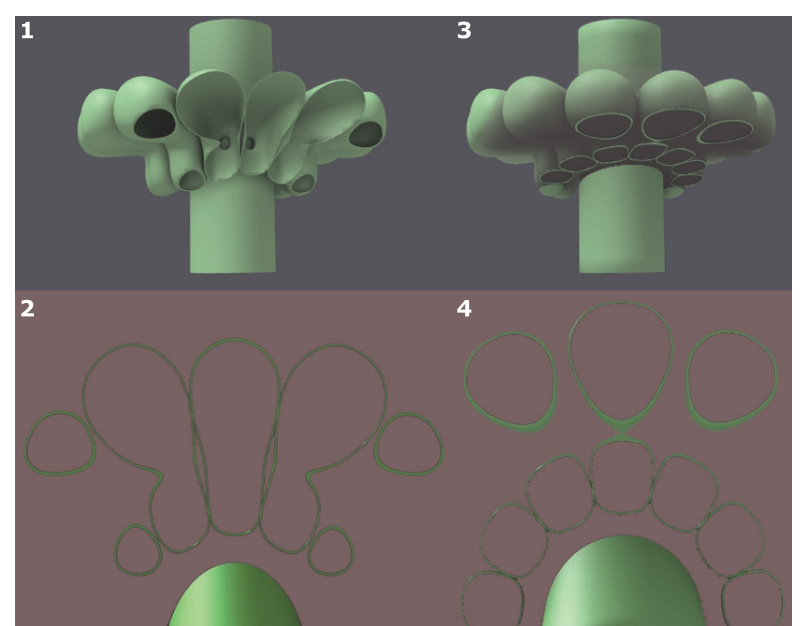

FIGURE 15. The laterals have the general shape of elbow tubes closed at both ends here (at the start of the reproductive stage). They communicate with the main axis through a small pore on the side of the elbow. 1-2. oblique sections $3 \mathrm{D}$ and $2 \mathrm{D}$ to compare with Figure 12.11. 3-4. oblique sections $3 \mathrm{D}$ and $2 \mathrm{D}$ to compare with Figure 8.3.

occasion of JK2018, the International Meeting around the Jurassic-Cretaceous Boundary (Muséum d'Histoire Naturelle de Genève, December 5-7, 2018). Special thanks go to Patrick Génot for permission to reuse 3 SEM photos from his DSc thesis, as well as an unpublished SEM photo. The first author (B.G.) is grateful for the support provided by the successive curators of paleontological collections (E.P. Munier-Chalmas and J. Pfender) at the Université Pierre et Marie Curie, first J.-P. Bellier, then I. Rouget, and last S. Jouve. The new SEM photos of Acetabularia (Figure 6.6-10) were taken by H. Dias Brito, Universidade Estadual Paulista, Rio Claro (São Paulo, Brazil). The manuscript also benefited from the constructive reviews of I.I. Bucur and F. Schlagintweit. Finally, the authors are very grateful to M. Hyžný, PE editor, for his support with the editing, and to P. Salvador who carefully revised the English text of the latest version of the manuscript.

\section{REFERENCES}

Alth, A. 1882. Die Versteinerungen des Niźniower Kalksteines. Beiträge zur Paläontologie Österreich-Ungarns und des Orients, I(3-4):183-332 (Pls. XVIII-XXIX).

Bassoullet, J.-P., Bernier, P., Conrad, M.A., Deloffre, R., and Jaffrezo, M. 1978. Les algues Dasycladales du Jurassique et du Crétacé. Geobios, Mémoire Spécial 2:1-330.

Berger, S. and Kaever, M.J. 1992. Dasycladales. An Illustrated Monograph of a Fascinating Algal Order. Thieme, Stuttgart. 
Bignot, G. 1982. Les Microfossiles. Dunod Université, Paris.

Bignot, G. 1985. Elements of Micropalaeontology. Graham and Trotman, London.

Bonotto, S., Lurquin, P., and Mazza, A. 1977. Recent advances in research on the marine alga Acetabularia. Advances in Marine Biology, 14:123-124, 124a, 125-250.

Cita, M.B. 1964. Micropaleontologia. III Edizione. La Goliardica, Milano.

Conrad, M.A., Praturlon, A., and Radoičić, R. 1974. The genus Actinoporella Gümbel in Alth 1882, Dasycladales, green algae. A revision. Geologica Romana, 13:1-15.

Costantin, J. 1925. Un important problème de paléontologie végétale (Les algues siphonées calcaires). Annales des Sciences Naturelles (Botanique), 11(7):793-799.

De Castro, P. 1997. Introduzione allo studio in sezione sottile delle Dasicladali fossili. Quaderni dell'Accademia Pontaniana, 22:1-261.

Deloffre, R. and Génot, P. 1982. Les algues Dasycladales du Cénozoïque. Bulletin des Centres de Recherches Exploration-Production elf-Aquitaine, Mémoire 4:1-247.

Deloffre, R. and Granier, B. 1992. Inventaire des algues Dasycladales fossiles. 1ère partie - Les algues Dasycladales du Tertiaire. Revue de Paléobiologie, 11(2):331-356.

Elliott, G.F. 1968. Permian to Palaeocene calcareous algae (Dasycladaceae) of the Middle East. Bulletin of the British Museum (Natural History) Geology, Supplement 4:1-111 (24 Pls.).

Emberger, J. 1955. Les Clypéines (algues siphonées verticillées) des Monts des Oulad Naïl (Atlas saharien, Algérie). Bulletin de la Société Géologique de France (6e série), V:543-552.

Emberger, J. 1960. Esquisse géologique de la partie orientale des Monts des Oulad-Naïl, Atlas saharien, Algérie. Publications du Service de la Carte Géologique de l'Algérie, Bulletin, Nouvelle Série, 27:1-398.

Emberger, L. 1968. Les Plantes Fossiles dans leurs Rapports avec les Végétaux Vivants. 2e Édition. Masson et Cie, Paris.

Endo, R. 1961. Phylogenetic relationships among the calcareous algae. The Science Reports of the Saitama University, Series B, Commemorative Volume dedicated to Professor Riuji Endo:1-52 (17 Pls.).

Favre, J. 1927. Sur la présence de Clypeina jurassica n. sp., algue siphonée calcaire, dans le Portlandien de divers points du Jura méridional. Compte-Rendu des Séances de la Société de Physique et d'Histoire Naturelle de Genève, 44(1):49-50.

Favre, J. 1932. Présence d'une nouvelle espèce d'algue calcaire siphonée dans le Valanginien du Jura central, Clypeina inopinata n. sp. Eclogæ Geologicæ Helvetiæ, 25(1):11-16.

Favre, J. and Richard, A. 1927. Étude du Jurassique supérieur de Pierre-Châtel et de la cluse de la Balme (Jura méridional). Mémoires de la Société Paléontologique Suisse, 44:1-39 (3 Pls.).

Génot, P. 1978. Les Dasycladacées du Paléocène Supérieur et de l'Éocène du Bassin de Paris. PhD Thesis, Université Bordeaux I.

Génot, P. 1980. Les Dasycladacées du Paléocène supérieur et de l'Éocène du Bassin de Paris. Mémoires de la Société Géologique de France, LIX (N.S.), 138:1-40 (25 Pls.).

Génot, P. 1987. Les Chlorophycées Calcaires du Paléogène d'Europe Nord-Occidentale (Bassin de Paris, Bretagne, Cotentin, Bassin de Mons). DSc Thesis, Université de Nantes.

Génot, P. 2009. Cenozoic Dasycladales. A Photo-Atlas of Lutetian Species from French Cenozoic Basins. Carnets de Géologie, Madrid. https://doi.org/10.4267/2042/21981

Granier, B. 1986. Algues Chlorophyceae du Jurassique terminal et du Crétacé inférieur en Alicante. Mediterranea, 5:5-96.

Granier, B. 1994. The genus Actinoporella (Gümbel in Alth, 1881) and its representatives. A review. In Proceedings of the International Symposium and Field-Meeting "Alpine Algae '93". Beiträge zur Paläontologie, 19:113-127.

Granier, B. 2010. Bucurella, a new genus of the Tribe Thyrsoporelleae (fossil Dasycladalean algae). Carnets Geol., CG2010_A03, 10(A03):1-37. https://doi.org/10.4267/2042/32425

Granier, B. 2012. The contribution of calcareous green algae to the production of limestones: A review. In Basso, D. and Granier, B. (eds.), Calcareous Algae and the Global Change: From Identification to Quantification. Geodiversitas, 34(1):35-60. https://doi.org/10.5252/ g2012n1a3.

Granier, B. 2015. Algas calcárias marinhas bentônicas no Cretáceo do Brasil, p. 518-567. In Dias-Brito, D. and Tibana, P. (eds.), Atlas dos Calcários do Cretáceo do Brasil: um Atlas. IGCE/UNESP/Rio Claro, UNESPetro, Obra 1.

Granier, B. 2019a. Observations on some Actinoporellas (Chlorophyta, Polyphysaceae). Revision of the Jacques Emberger Collection. Part 1. Carnets Geol., 19(7):113-140. https://doi.org/10.4267/2042/70196 
Granier, B. 2019b. Dual biozonation scheme (benthic foraminifera and "calcareous" green algae) over the Jurassic-Cretaceous transition. Another plea to revert the system boundary to its historical Orbigny's and Oppel's definition. In Granier, B. (ed.), Special issue on "The Transition of the Jurassic to the Cretaceous: an Early XXIth Century Holistic Approach". Cretaceous Research, 93:245-274. https://doi.org/10.1016/j.cretres.2018.08.024

Granier, B. and Boichard, R. 2017. Sedimentological investigation on Holocene deposits in the Mussafah channel (Abu Dhabi, United Arab Emirates). Carnets Geol., 17(3):39-104. https:// doi.org/10.4267/2042/62267

Granier, B. and Deloffre, R. 1993. Inventaire critique des algues Dasycladales fossiles. 2ème partie - Les algues Dasycladales du Jurassique et du Crétacé. Revue de Paléobiologie, 12(1):19-65.

Granier, B. and Dias-Brito, D. 2016. On the fossil alga Elianella elegans Pfender and Basse, 1948, and its so-called lookalikes, with description of Elianella brasiliana n. sp. Revision of the Juliette Pfender Collection. Part 1. Carnets Geol., 16(6):213-229. https://doi.org/10.4267/ 2042/59920

Granier, B.R.C. and Lethiers, A. 2017. Draconisella mortoni sp. nov., a Mizzia-like Dasycladalean alga from the Lower Cretaceous of Oman. Palaeontologia Electronica 20.1.6A:1-14. https://doi.org/10.26879/743

Granier, B. and Lethiers, A. 2019. Revision of the fossil genus Clypeina (Michelin, 1845), Chlorophyta, Dasycladales, Polyphysaceae: Systematic position of Clypeina sulcata (von Alth, 1882), C. jurassica (Favre \& Richard, 1927), and C. inopinata Favre, 1932. p. 38. In Granier, B. (ed.), JK2018 - International Meeting around the Jurassic-Cretaceous Boundary (Geneva, December 5-7, 2018) - Abstract Volume. Carnets de Géologie, Madrid. https:// doi.org/10.4267/2042/69811

Granier, B. and Sander, N.J. 2013. The XXIst Century (the 100th Anniversary) Edition of the "New Studies on Triassic Siphoneae verticillatae" by Julius von Pia. Carnets de Géologie, Madrid. https://doi.org/10.4267/2042/48735

Johnson, J.H. 1964. The Jurassic algae. Quarterly of the Colorado School of Mines, 59(2):1-129.

Joukowsky, E. and Favre, J. 1913. Monographie géologique et paléontologique du Salève. Mémoires de la Société de Physique et d'Histoire Naturelle de Genève, 37(4):295-523.

Mathieu, R., Bellier, J.-P., and Granier, B. 2011. Manuel de Micropaléontologie. Carnets de Géologie, Madrid. https://doi.org/10.4267/2042/45793

Michelin, H. 1840-1847. Iconographie Zoophytologique. Description par Localités et Terrains des Polypiers Fossiles de France et Pays Environnants. P. Bertrand, Paris.

Morellet, J. 1950. Contribution à l'étude de Clypeina jurassica J. Favre (algue siphonée calcaire), d'après de remarquables échantillons du Jurassique d'Algérie. Bulletin de la Société Géologique de France (5e série), 20(7-9):399-402 (PI. XXII).

Morellet, L. and Morellet, J. 1918. Observations sur le genre Clypeina Michelin. Bulletin de la Société Géologique de France (4e série), 18(1-2):102-105.

Moret, L. 1943. Manuel de Paléontologie Végétale. Masson et Cie, Paris.

Munier-Chalmas, E.P. 1877. Observations sur les algues calcaires appartenant au groupe des Siphonées verticillées (Dasycladées Harv.) et confondues avec les Foraminifères. Comptes Rendus des Séances de l'Académie des Sciences, 85(18):814-817.

Parker, W.K. and Jones, T.R. 1860. L. On the nomenclature of the Foraminifera. The Annals and Magazine of Natural History (3rd Series), V:466-477.

Pfender, J. 1927a. Sur la présence de Clypeina Michelin dans les couches de passage du Jurassique au Crétacé, en Basse-Provence calcaire; de son identité avec l'Organisme A du Purbeckien marin au Salève (Joukowsky et Favre). Bulletin de la Société Géologique de France (4e série), 27(1-2):89-94 (PI. V).

Pfender, J. 1927b. Sur la présence de Clypeina Michelin dans les couches de passage du Jurassique au Crétacé, en Basse-Provence calcaire; de son identité avec l'organisme A du Purbeckien marin au Salève (Joukowsky et Favre). Compte Rendu Sommaire des Séances de la Société Géologique de France, 1927(4):28.

Pia, J. 1920. Die Siphonae verticillatae vom Karbon bis zur Kreide. Abhandlungen der Zoologisch-Botanischen Gesellschaft in Wien, 11(2):1-263 (8 Pls.).

Pia, J. 1927. Dasycladaceae (Siphoneae verticillatae). p. 61-87. In Hirmer, M. (ed.), Handbuch der Paläobotanik. R. Oldenbourg, München.

Radoičić, R. 1969. A new Lower Cretaceous Dasycladacea, Clypeina pejovici, and note on some Clypeinae. Geologica Romana, 8:71-84. 
Remane, J. 1969. Morphological and statistical analysis of Clypeina jurassica (Favre) (Dasycladaceae) by means of serial sections. Geologica Romana, 8:85-116.

Rezak, R. 1957. Occurrence of Clypeina in the Eocene of Florida. Micropaleontology, 3:281-286.

Schlagintweit, F., Dieni, D., and Radoičić, R. 2009. Two look-alike dasycladalean algae: Clypeina isabellae Masse, Bucur, Virgone and Delmasso, 1999 from the Berriasian of Sardinia (Italy) and Clypeina loferensis sp. $\mathrm{n}$. from the upper Jurassic of the Northern Calcareous Alps (Austria). Geoloski Anali Balkanskog Poluostrva, 70:43-59. https://doi.org/10.2298/ GABP0970043S

Schlagintweit, F., Gawlick, H.-J., and Lein, R. 2005. Mikropaläontologie und Biostratigraphie der Plassen-Karbonatplattform der Typlokalität (Ober-Jura bis Unter-Kreide, Salzkammergut, Österreich). Journal of Alpine Geology (Mitteilungen der Gesellschaft der Geologie- und Bergbaustudenten in Österreich), 47:11-102.

Sokač, B., Grgasović, T., and Husinec, A. 2014. Clypeina lagustensis n.sp., a new calcareous alga from the Lower Tithonian of the Lastovo Island (Croatia). Geologia Croatica, 67(2):7586. https://doi.org/10.4154/GC.2014.06

Valet, G. 1968. Contribution à l'étude des Dasycladales. 1. Morphogenèse. Nova Hedwigia, 16:21-82 (23 Pls.). 